\title{
Anterior Cruciate Ligament Injury Risk Factors by Landing Error Scoring System (LESS) and Muscle Activities during Drop Vertical Jump for Overweight Females
}

\author{
Minji HwangBo and Beeoh Lim* \\ Department of Physical Education, Chung-Ang University, Seoul, Korea
}

\author{
Article Info \\ Received 2021.10.01. \\ Revised 2021.11.29. \\ Accepted 2021.12.10. \\ Correspondence* \\ Beeoh Lim \\ bolim@cau.ac.kr \\ Key Words \\ Overweight females, \\ Anterior cruciate ligament, \\ Landing error scoring system, \\ Muscle activity
}

PURPOSE The purpose of this study was to investigate the risk factors for anterior cruciate ligament injury using the Landing Error Scoring System (LESS) and muscle activity during the drop vertical jump for overweight females. METHODS The body mass index was $18.5-22.9 \mathrm{~kg} / \mathrm{m}^{2}$ for normal weight females and $23-24.9 \mathrm{~kg} / \mathrm{m}^{2}$ for overweight females among 10 participants aged 20-30 years classified into groups of participants without any injury history and those who were right-footed. An automatic heightweight machine, body composition analyzer, diagnostic imaging, electromyography with the LESS, and muscle activity analysis were used for measurements. The difference in muscle activity between the normal weight and overweight females was evaluated by independent t-test. RESULTS Overweight females had a smaller angle of knee bending during the drop vertical landing, leading to a smaller knee curve angle. In addition, they landed with an unbalanced foot touch on the ground inclined backward, thereby breaking the whole body balance. Overweight females had an incorrect posture compared with normal weight females, with higher LESS points. The muscle activity of the rectus femoris was higher than that of the biceps femoris, indicating a higher load on the muscle. CONCLUSIONS Overweight females take more load on the knee joint and cannot absorb the impact force properly. These results suggest a higher risk of anterior cruciate ligament injury in overweight females.

\begin{abstract}
서론
전방십자인대 부상은 무릎관절의 불안정성과 무력감을 증가시켜서 일 상생활에 지장을 주고 스포츠 활동의 참여를 제한시키며, 치료를 받 은 후에도 퇴행성관절염의 발병률을 증가시키는 매우 치명적인 부상 이다(Hewett, Myer \& Ford, 2006). 전방십자인대 부상은 선수와의 충 돌로 인하여 발생하는 접촉성 부상보다 신체적 접촉 없이 자신의 체중 에 의해 발생하는 비접촉성 부상이 더 많으며(Kim \& Lim, 2011), 방향 전환, 점프 후 착지, 드롭수직 점프와 같은 상황에서 부상이 발생한다 (Hewett et al., 2006; Kim \& Lim, 2011; Padua. DiStefano, Beutler, Motte, DiStefano \& Marshall, 2015). 특히, 드롭수직 점프 동작은 농 구 리바운드 후 골밑 슛이나 배구 블로킹 후 스파이크 등과 같은 스포
\end{abstract}

(c) This is an open-access article distributed under the terms of the Creative Commons Attribution Non-Commercial License (http://creativecommons.org/ licenses/by-nc/4.0/), which permits unrestricted non-commercial use, distribution, and reproduction in any medium, provided the original work is properly cited.
츠 상황에서 많이 발생하는데, 강한 충격력이 무릎 관절에 부하를 미쳐 서 전방십자인대 손상의 주요한 원인이 되는 동작이다(Padua et al., 2015). 잘못된 자세로 착지할 경우에는 부상으로 이어질 수 있기 때문 에, 안정된 자세로 착지하는 것은 매우 중요하다(Hewett et al., 2006; $\operatorname{Lim}, 2007)$.

점프 후 착지 과정에서 발생하는 부상 비율은 여성이 남성에 비하여 2 9배 더 높은 것으로 알려져 있다(Hewett et al., 2006). 여성이 남성 에 비하여 부상 위험률이 높은 이유는 점프 후 착지할 때 남성들보다 무 릎과 엉덩 관절을 덜 굽히며(Lim \& Choe, 2009), 여성들은 남성들보 다 대퇴사두근의 근력이 약하기 때문이다(Ahmad, Clark, Heilmann, Schoeb, Gardner \& Levine, 2006). 착지 시 근육의 적절한 활성화는 무릎 부상을 예방하는 주요 요인이며(Hewett et al., 2006; Ahmad et al., 2006), 무릎관절을 펴는 주동근인 넙다리곧은근과 무릎관절을 굽 히는 주동근인 넙다리두갈래근의 공동작용은 무릎의 전방밀림과 외전 동작을 막아주어 무릎관절을 보호한다(Ahmad et al., 2006; Hewett et al., 2006; Lim \& Choe, 2009). 특히, 무릎의 굽힘근과 폄근의 효과적 
인 동원은 전방십자인대의 부상을 감소시키는 반면, 비대칭적인 근육의 동원은 부상을 증가시킨다(Ahmad et al., 2006; Hewett et al., 2006).

전방십자인대에 영향을 주는 다른 요인은 과도한 체중으로, 특 히 비만인 사람들은 정상 체중을 가지고 있는 사람들보다 하지 관절 에 가해지는 큰 부하가 발생되어 하지 근골격계에 많은 영향을 준다 (Korean Society for the Study Obesity, 2018; Goulding, Taylor, Jones, McAuley, Manning \& Williams, 2000). 체중이 많이 나 갈수록 발목과 무릎의 큰 부하로 인하여 근 피로도가 증가할 수 있 으며 부상 유발의 위험 또한 증가된다(Lee \& Jung, 2018; Smith, Roan \& Lee, 2010). Andersen, Crespo, Bartlett, Bathon \& Fontaine(2003)은 비만과 하지 관절의 부상 위험도를 신체질량지수 (Body Mass Index, BMI) 기준으로 분석한 결과 BMI 수치가 높을수 록 하지 관절에 가해지는 부하의 크기가 증가하여 무릎, 엉덩이, 허 리 관절의 통증이 많았다고 보고하였다. 또한, Moon, Cho, Lim \& $\operatorname{Lim}(2019)$ 은 박스 높이 $(30 \mathrm{~cm}$ 와 $45 \mathrm{~cm}$ )와 거리(신장의 $50 \%$ 와 $75 \%$ ) 과제 별로 성인 여성의 근육 비율은 전방십자인대 손상과 밀접한 관 련이 있다고 하였다. 여러 선행 연구에 의하면, 과도한 체중을 가지고 있는 여성인 경우 점프 후 착지 시 무릎 관절에 많은 부하를 주어 부 상 위험이 증가한 것으로 보고하였다(Goulding et al., 2000; Lee \& Jung, 2018; Smith et al., 2010).

최근까지 전방십자인대 부상 위험 원인을 규명하기 위해서 지면반 력을 측정하는 시스템과 3차원 동작분석 시스템 장비 등을 사용해왔 지만(Hewett et al., 2006; Kim \& Lim, 2011; Lim, 2007; Ahmad et al., 2006), 실험대상자에게 적용하는 것은 시간적, 비용적 문제들 이 많기 때문에 그 대안으로 착지오류점수(Landing Error Scoring System: LESS)가 개발되었다(Padua, Marshall, Boling, Thigpen, Garrett, \& Beutler, 2009). LESS는 점프와 착지가 이루어지는 과정 에서 발생되는 잠재적인 고위험 움직임 패턴(오류)를 평가하는 도구 이며, 발, 무릎, 엉덩이 및 몸통의 위치와 자세를 비디오 분석을 통하 여 평가하는 시스템이다(Padua et al., 2009). 또한, 기존의 연구에서 전방십자인대 부상의 원인을 밝히기 위한 다양한 방법이 시도되었지 만(Hewett et al., 2006; Kim \& Lim, 2011; Lim, 2007; Ahmad et al., 2006), 스포츠 상황에서 부상과 연관이 있는 드롭수직점프 동작 을 수행할 때 전방십자인대 부상이 발생하는 자세 분석과 근육 활성 도를 분석한 연구는 미비하다. 따라서 일반인 정상 체중뿐만 아니라, 과체중이 무릎 관절의 부상 유발 위험이 증가된다는 선행연구 결과에 따라 과체중 여성들을 대상으로 전방십자인대 부상 방지를 위한 착지 오류점수(LESS)와 하지 근육 활성도에 대한 이해를 바탕으로 한 연구 가 필요한 실정이다. 과체중 여성들도 스포츠 현장에서 착지 후 점프 같은 위험한 동작을 수행하기에 본 연구에 착지 후 점프 과제를 선정 하였다. 본 연구의 목적은 여성 집단 내에서 정상 체중과 과체중을 대 상으로 드롭수직점프 시 두 집단 간의 착지오류점수(LESS)와 하지의 근 활성도를 비교 분석하여 과체중 여성들의 전방십자인대 부상 위험 요인을 규명하는 것이다.

\section{연구방법}

\section{연구대상}

본 연구의 대상자는 실험 6 개월 이내에 수술 경력 또는 하지의 근골격
계에 부상 이력이 없고, 오른발이 주동발인 20 30대 여성의 자발적 인 참여로 모집하였다. 실험 전 자동신장체중계와 체성분분석기를 이 용하여 신장 $(\mathrm{cm})$ 과 체중 $(\mathrm{kg})$, 체질량지수 $\left(\mathrm{kg} / \mathrm{m}^{2}\right)$ 를 측정하였다. 대한 비만학회 홈페이지(http://general.kosso.or.kr)에서 제시한 체질량 지수를 이용하여 $18.5-22.9 \mathrm{~kg} / \mathrm{m}^{2}$ 내에 있는 10 명을 정상 체중(나이: $25.10 \pm 2.38$ 세, 신장: $163.24 \pm 3.92 \mathrm{~cm}$, 체중: $54.50 \pm 3.55 \mathrm{~kg}$, 체 질량지수: $\left.20.35 \pm 1.14 \mathrm{~kg} / \mathrm{m}^{2}\right), 23-24.9 \mathrm{~kg} / \mathrm{m}^{2}$ 내에 있는 10 명(나이: $23.80 \pm 2.74$ 세, 신장: $165.90 \pm 5.36 \mathrm{~cm}$, 체중: $65.58 \pm 4.81 \mathrm{~kg}$, 체질 량지수: $\left.23.81 \pm 0.76 \mathrm{~kg} / \mathrm{m}^{2}\right)$ 을 과체중으로 분류하였다.

실험에 참여한 연구대상자들에게 연구의 목적, 방법 및 실험에 따르 는 위험성에 대하여 충분히 설명한 후에 실험 참가에 대한 서면동의서 를 받았다. 본 연구는 C대학교 생명윤리위원회에서 연구승인을 받았다 (IRB 승인번호: 1041078-201802-HRBR-039-01). IRB 연구승인을 받을 때, 드롭수직점프가 하지에 상당히 부하가 많이 가는 동작이지만, 농구의 리바운드 후 골밑 슛이나 배구 블로킹 후 스파이크 동작과 같은 스포츠 상황에서 꼭 필요하기 때문에, 안전과 위급상황을 책임질 운동 사 및 스포츠지도사의 관리 하에 본 연구를 수행하였다.

\section{실험절차}

\section{1. 사전교육 및 실험환경 적응}

실험실에는 비디오카메라를 착지위치에서 $3.5 \mathrm{~m}$ 의 거리를 두고 연 구대상자의 오른쪽 무릎관절 방향의 측면과 정면 $1.2 \mathrm{~m}$ 의 높이에 각 각 설치하였다(Padua et al., 2009). 실험장비 배치도는 〈Figure 1〉과 같다.

실험 참가 동의서에 서명을 한 연구대상자는 신체 조건에 맞는 반팔 과 반바지를 착용한 후 신체적 특성 평가를 위한 신체구성을 측정하 였다. 드롭수직점프 동작이 익숙하지 않은 연구대상자에게 동작 설명 과 시범을 보였으며 드롭수직점프 동작은 〈Figure 2〉와 같다. 실험 도 중에 발생될 수 있는 부상을 예방하기 위해서 약 10 분간의 스트레칭과

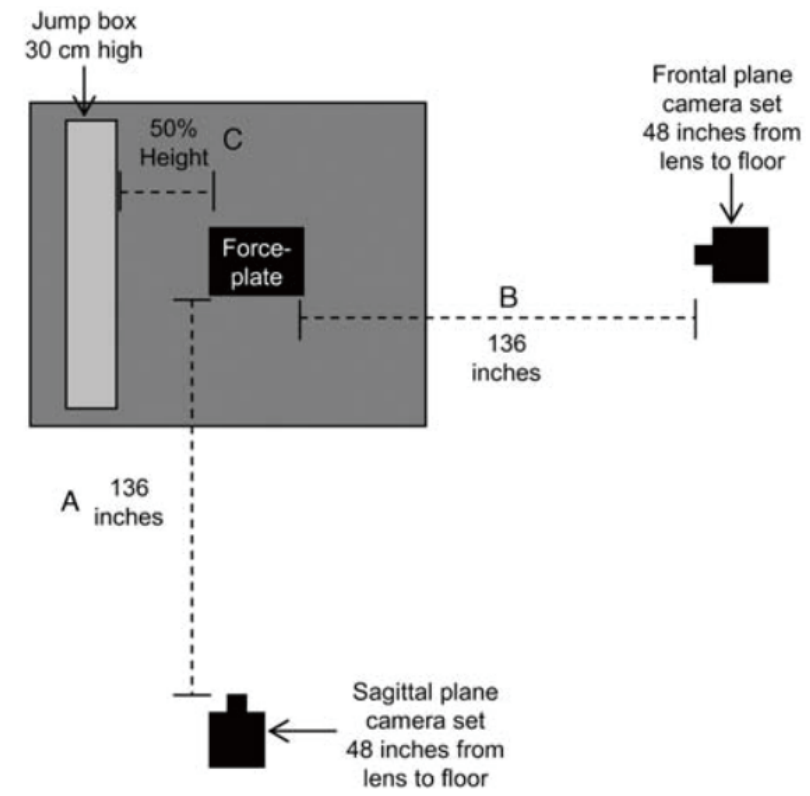

Fig. 1. Experimental setup 

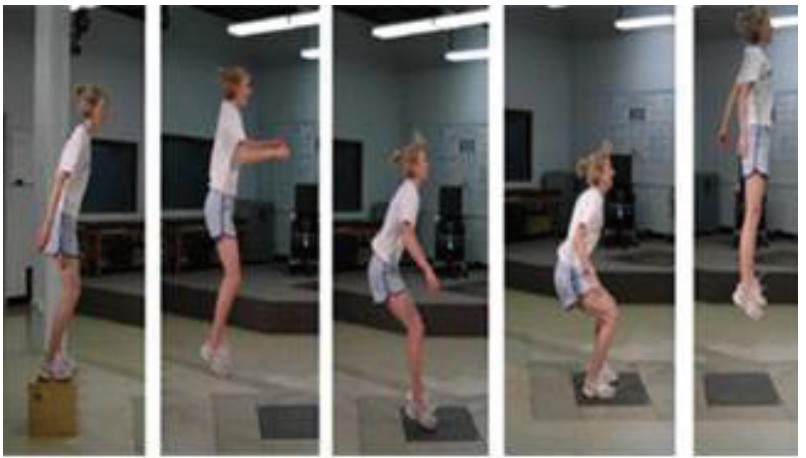

Fig. 2. Drop vertical jump task (Padua et al., 2009)

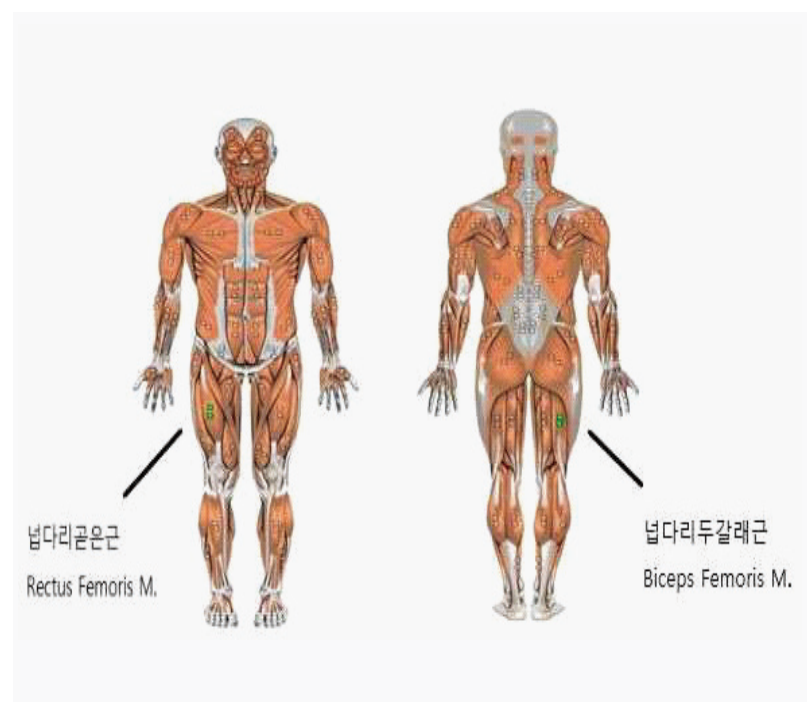

Fig. 3. Electrode attachment

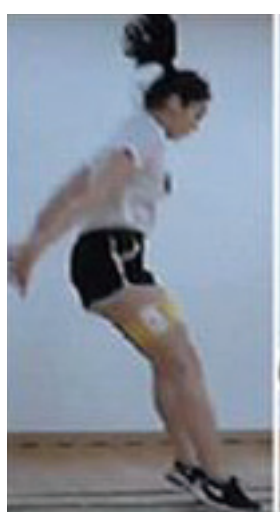

E1

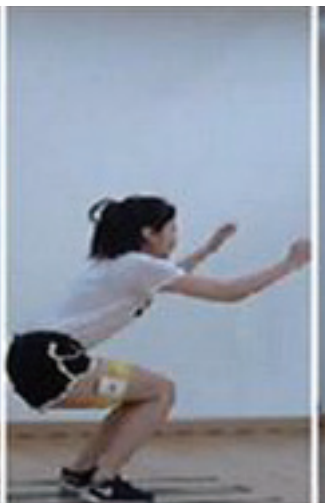

E2

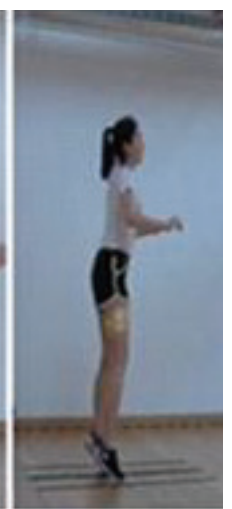

E3

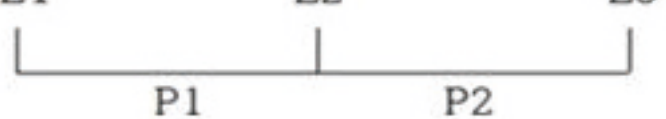

Fig. 4. Event and phase
동작 연습시간을 제공한 후 본 실험을 진행하였다.

\section{2. 근전도 측정부위 및 전극부착}

본 연구에서 근전도 측정 부위는 전방십자인대 부상과 밀접하게 관 련이 있으며, 드롭수직점프 시 영향을 주는 넙다리곧은근과 넙다리두 갈래근으로 설정하였다(Peng, Kernozek \& Song, 2010). 근전도 자 료의 정확도를 높이기 위해 알코올 솜을 사용하여 피부 외피를 깨끗 하게 소독한 후 오른쪽 넙다리곧은근(rectus femoris)과 넙다리두갈 래근(biceps femoris)에 전극을 부착하였다. 전극부착 위치는 '근전 도 분석'과 'Seniam'을 참조하였으며(Hermens et al., 1999), 동작 시 전극이 떨어지지 않도록 부착한 전극 위에 테이핑 처리를 하였다 〈Figure 3〉.

\section{3. 최대 수의적 수축 측정}

최대 수의적 수축(Maximal Voluntary Contraction: MVC)을 적 용하여 근전도 신호를 표준화하였으며, 각 근육별 $\mathrm{MVC}$ 측정방법은 MUSCLE TESTING을 참조하였다(Henlen, 2007). 각 근육별로 최대 한 발휘할 수 있는 동작을 5 초 간 유지하여 3회씩 반복 측정하였으며, 각 동작의 수행 사이에 1 분간 휴식을 제공하였다.

\section{4. 드롭수직점프 동작 실험}

연구대상자는 $30 \mathrm{~cm}$ 높이의 도약대 위에서 '시작' 신호를 듣고 나서 본인 신장의 $50 \%$ 거리가 멀어진 지점으로 뛰어내린 후, 지면에 닿는 즉시 최대 수직높이로 점프를 수행하였다. 연구대상자의 피로를 최소 화하기 위하여 1 회 동작 후 3 분간 휴식을 취하였다. 드롭수직점프 동 작 시 중심을 못 잡고 흔들리거나 넘어지는 경우엔 무효처리를 하였 으며, 성공적인 착지 동작을 비디오카메라에 영상으로 기록하였다.

\section{자료처리 및 분석}

\section{1. 이벤트 및 구간 설정}

착지 시 발생되는 부상은 발이 지면에 닿는 순간인 착지 초기 접촉 시점과 충격을 흡수하기 위해 무릎을 굴곡시키는 과정에서 발생하므 로(Hewett et al., 2006; Lim, 2007), 본 연구의 분석 구간은 다음과 같이 정하였다〈Figure 4〉.

- E1(Event 1): 점프 후 발이 지면에 닿기 시작하는 착지 초기 접촉 시점

- E2(Event 2): 수직점프하기 전 무릎관절의 최대 굴곡 시점

- E3(Event 3): 발끝이 떨어지기 직전의 무릎관절 최대 신전 시점

- P1(phase 1): E1에서 E2 국면

- P2(phase 2): E2에서 E3 국면

\section{2. 근전도 자료처리}

본 연구는 무선 근전도 시스템(DTS Probe Transmitter, Noraxon $\mathrm{USA}$ )을 사용하였으며 근전도 데이터 수집 절차는 초당 $1,500 \mathrm{~Hz}$ 의 신호로 데이터를 수집하였다. 원근전도(raw EMG)는 $10 ~ 400 \mathrm{~Hz}$ 필 터링(band pass filter) 후 정류(full wave rectification)하였다. 각 구간에서 넙다리곧은근과 넙다리두갈래근의 근 활성도 변화를 비 교분석하기 위하여 RMS(Root mean square)을 이용하여 평활화 (smoothing)하였으며, 실험 전 측정한 최대 수의적 수축 값(MVC)과 실험 후 데이터 값을 비교 분석하였다. 
Table 1. Operational definitions for individual LESS items (Padua et al., 2015)

\begin{tabular}{|c|c|c|}
\hline Landing error scoring system item & Operational definition of error & Scoring \\
\hline Knee flexion: initial contact & The knee is flexed less than $30^{\circ}$ at initial contact. & $\begin{array}{l}0=\text { Absent } \\
1=\text { Present }\end{array}$ \\
\hline Hip flexion: initial contact & The thigh is in line with the trunk at initial contact. & $\begin{array}{l}0=\text { Absent } \\
1=\text { Present }\end{array}$ \\
\hline Trunk flexion: initial contact & The trunk is vertical or extended on the hips at initial contact. & $\begin{array}{l}0=\text { Absent } \\
1=\text { Present }\end{array}$ \\
\hline Ankle plantar flexion: initial contact & The foot lands heel to toe or with a flat foot at initial contact. & $\begin{array}{l}0=\text { Absent } \\
1=\text { Present }\end{array}$ \\
\hline Medial knee position: initial contact & The center of the patella is medial to the midfoot at initial contact. & $\begin{array}{l}0=\text { Absent } \\
1=\text { Present }\end{array}$ \\
\hline Lateral trunk flexion: initial contact & The midline of the trunk is flexed to the left or the right side of the body at initial contact. & $\begin{array}{l}0=\text { Absent } \\
1=\text { Present }\end{array}$ \\
\hline Stance width: wide & $\begin{array}{l}\text { The feet are positioned greater than shoulder width apart (acromion processes) at initial } \\
\text { contact. }\end{array}$ & $\begin{array}{l}0=\text { Absent } \\
1=\text { Present }\end{array}$ \\
\hline Stance width: narrow & $\begin{array}{l}\text { The feet are positioned less than shoulder width apart (acromion processes) at initial } \\
\text { contact. }\end{array}$ & $\begin{array}{l}0=\text { Absent } \\
1=\text { Present }\end{array}$ \\
\hline Foot position: external rotation & $\begin{array}{l}\text { The foot is externally rotated more than } 30^{\circ} \text { between initial contact and maximum knee } \\
\text { flexion. }\end{array}$ & $\begin{array}{l}0=\text { Absent } \\
1=\text { Present }\end{array}$ \\
\hline Foot position: internal rotation & $\begin{array}{l}\text { The foot is internally rotated more than } 30^{\circ} \text { between initial contact and maximum knee } \\
\text { flexion. }\end{array}$ & $\begin{array}{l}0=\text { Absent } \\
1=\text { Present }\end{array}$ \\
\hline $\begin{array}{l}\text { Symmetric initial foot contact: initial } \\
\text { contact }\end{array}$ & $\begin{array}{l}\text { One foot lands before the other foot or } 1 \text { foot lands heel to toe and the other foot lands toe } \\
\text { to heel. }\end{array}$ & $\begin{array}{l}0=\text { Absent } \\
1=\text { Present }\end{array}$ \\
\hline Knee-flexion displacement & The knee flexes lass than $45^{\circ}$ between initial contact and maximum knee flexion. & $\begin{array}{l}0=\text { Absent } \\
1=\text { Present }\end{array}$ \\
\hline Hip-flexion displacement & $\begin{array}{l}\text { The thigh does not flex more on the trunk between initial contact and maximum knee } \\
\text { flexion. }\end{array}$ & $\begin{array}{l}0=\text { Absent } \\
1=\text { Present }\end{array}$ \\
\hline Trunk-flexion displacement & The trunk does not flex more between initial contact and maximum knee flexion. & $\begin{array}{l}0=\text { Absent } \\
1=\text { Present }\end{array}$ \\
\hline Medial-knee displacement & $\begin{array}{l}\text { At the point of maximum medial knee position, the center of the patella is medial to the } \\
\text { midfoot. }\end{array}$ & $\begin{array}{l}0=\text { Absent } \\
1=\text { Present }\end{array}$ \\
\hline Joint displacement & $\begin{array}{l}\text { Soft: the participant demonstrates a large amount of trunk, hip, and knee displacement. } \\
\text { Average: the participant has some, but not a large amount of, trunk, hip, and knee } \\
\text { displacement. }\end{array}$ & $\begin{array}{l}0=\text { Soft } \\
1=\text { Average }\end{array}$ \\
\hline \multirow[t]{2}{*}{ Overall impression } & $\begin{array}{l}\text { Stiff: the participant goes through very little, if any, trunk, hip, and knee displacement. } \\
\text { Excellent: the participant displays a soft landing with no frontal-plane or transverse- } \\
\text { plane motion. }\end{array}$ & $\begin{array}{l}2=\text { Stiff } \\
0=\text { Excellent }\end{array}$ \\
\hline & $\begin{array}{l}\text { Average: all other landings. } \\
\text { Poor: the participant displays large frontal-plane or transverse-plane motion, or the } \\
\text { participant displays a stiff landing with some frontal-plane or transverse-plane motion. }\end{array}$ & $\begin{array}{l}1=\text { Average } \\
2=\text { Poor }\end{array}$ \\
\hline
\end{tabular}




\section{3. 착지오류점수 평가}

착지오류점수는 〈Table 1〉에서 보는바와 같이, 기록된 영상에서 발 이 지면에 닿기 시작하는 착지 초기 접촉 시점과 수직점프하기 전 무 릎관절의 최대 굴곡 시점에서 잘못된 착지동작(오류)를 찾아내어 점 수를 평가하였다(Padua et al., 2015). 측면 영상에서 총 8가지 항 목으로 최고 9점의 오류점수를 확인하였으며, 정면 영상에서 총 9가 지 항목으로 최고 8점의 오류점수를 확인하였다. 마지막으로 정면과 측면의 영상을 종합적으로 판단하여 0 2점을 부가하였다. LESS 종 합점수는 19점 척도에 기반을 두고 있으며, LESS에서 우수한 착지 (excellent)는 4점 이하, 좋은(good) 착지는 4점 초과 5점 이하, 보통 (moderate) 착지는 5점 초과 6점 이하, 나쁜(poor) 착지는 6점 초과 로 보고 있다(Padua et al., 2009).

\section{4. 영상분석}

연구대상자들의 착지오류점수(LESS) 각도 계산은 동영상 분석 프 로그램인 키노베아(Kinovea ver. 0.8.15, software, www.kinovea. org)를 사용하여 LESS 평가기준에 맞게 분석하였다. 연구대상자들의 착지오류점수 각도는 선행연구(Cho, An, Cho \& Lim, 2015)에서 기 초하여 분석하였다〈Figure 5〉. 시상면 또는 관상면 상의 착지오류점 수 각도를 산출하는데 있어서 오류를 줄이기 위해서 수평계를 사용하 여 카메라를 지면과 수평 및 시상면에 수직이 되도록 설치하였다.

\section{통계 처리}

본 연구에서 측정된 자료는 SPSS(Version 18.0) 통계 프로그램을 이용 하여 분석하였다. 정상 체중 여성과 과체중 여성의 집단 간 착지오류점 수와 하지 근활성도 차이를 비교하기 위해서 독립표본 $t$ 검정을 실시하 였으며, 유의수준은 $p<.05$ 로 설정하였다.

\section{연구결과}

착지오류점수 평가

정상체중과 과체중 여성의 두 집단 간 착지오류점수를 비교한 결과
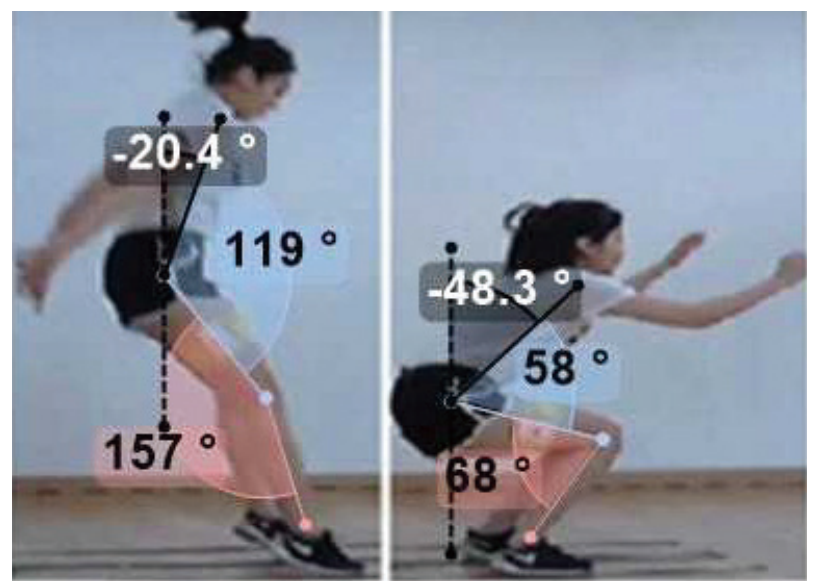

Fig. 5. LESS angle definition (trunk, hip and knee flexion angle)
는 〈Table 2 〉와 같다. LESS 1 번(착지 초기 접촉 시 무릎 굴곡 각도, $p=.001$ ), LESS 11 번(착지의 동시성, $p=.018$ ) 항목에서 통계적으로 유의미한 차이가 나타났다( $p<.05)$. 또한, 정상체중 여성과 과체중 여 성의 LESS 총점에서도 통계적으로 유의한 차이가 나타났다 $(p=.001)$. LESS 7, 8, 9, 10,12,13,14, 15 항목은 두 집단의 표준편차가 0 또 는 1 로 나타나서 $\mathrm{t}$ 값이 계산되지 않았다. 즉, 정상체중 여성과 과체 중 여성들의 LESS 점수는 다양한 항목에서 차이가 나는 것이 아니라 LESS 1번 항목과 LESS 11번 항목, LESS 총점에서만 유의미한 차이가 나타났다.

\section{넙다리곧은근과 넙다리두갈래근의 근 활성도 분석}

〈Table 3〉에서 보는 바와 같이, 착지초기에서 최대무릎굴곡 구간(P1 phase)에서 과체중 여성들의 넙다리곧은근의 최대 근 활성도가 정상 체중 여성에 비하여 유의하게 더 높게 나타났다( $p$ <.05). 또한, 최대무 릎굴곡에서 최대무릎신전 구간(P2 phase)에서 과체중 여성들의 넙다 리곧은근의 최대 근 활성도가 정상체중 여성에 비하여 유의하게 더 높 게 나타났다(p<.05)

Table 2. LESS score between normal and overweight females

(Mean \pm SD)

\begin{tabular}{|c|c|c|c|c|c|}
\hline Variables & Normal & Overweight & $t$ & $p$ & \\
\hline LESS 1 & $0.10 \pm 0.32$ & $0.80 \pm 0.42$ & -4.200 & .001 & $*$ \\
\hline LESS 2 & $0.10 \pm 0.32$ & $0.00 \pm 0.00$ & 1.000 & .343 & \\
\hline LESS 3 & $0.10 \pm 0.32$ & $0.30 \pm 0.48$ & -1.095 & .290 & \\
\hline LESS 4 & $0.20 \pm 0.42$ & $0.30 \pm 0.48$ & -0.493 & .628 & \\
\hline LESS 5 & $0.56 \pm 0.53$ & $0.90 \pm 0.32$ & -1.749 & .112 & \\
\hline LESS 6 & $0.30 \pm 0.48$ & $0.50 \pm 0.53$ & -0.885 & .388 & \\
\hline LESS 7 & $0.00 \pm 0.00$ & $0.00 \pm 0.00$ & - & & \\
\hline LESS 8 & $1.00 \pm 0.00$ & $1.00 \pm 0.00$ & - & & \\
\hline LESS 9 & $0.00 \pm 0.00$ & $0.00 \pm 0.00$ & - & & \\
\hline LESS 10 & $0.00 \pm 0.00$ & $0.00 \pm 0.00$ & - & & \\
\hline LESS 11 & $0.10 \pm 0.32$ & $0.60 \pm 0.52$ & -2.611 & .018 & $*$ \\
\hline LESS 12 & $0.00 \pm 0.00$ & $0.00 \pm 0.00$ & - & & \\
\hline LESS 13 & $0.00 \pm 0.00$ & $0.00 \pm 0.00$ & - & & \\
\hline LESS 14 & $0.00 \pm 0.00$ & $0.00 \pm 0.00$ & - & & \\
\hline LESS 15 & $1.00 \pm 0.00$ & $1.00 \pm 0.00$ & - & & \\
\hline LESS 16 & $0.40 \pm 0.52$ & $0.50 \pm 0.53$ & -0.429 & .673 & \\
\hline LESS 17 & $1.00 \pm 0.82$ & $1.50 \pm 0.53$ & -1.627 & .121 & \\
\hline LESS Total & $4.90 \pm 1.56$ & $7.40 \pm 1.26$ & -3.883 & .001 & * \\
\hline
\end{tabular}

$* p<.05$ 


\section{논의}

\section{착지 초기-최대무릎굴곡 구간(P1 phase)}

P1 구간은 점프 후 발이 지면에 닿기 시작하는 착지 초기 접촉 시점에 서 무릎관절이 최대로 굴곡 되는 시점까지의 구간이며, 착지오류점수 LESS를 활용하여 발, 무릎, 엉덩이 및 몸통의 위치와 자세를 집단 간 비교 분석하였다. LESS 분석 결과, 착지 초기 접촉 시 무릎의 굴곡 각 도(LESS 1번), 착지의 동시성(LESS 11번)에서 과체중 여성들이 정상 체중 여성들에 비하여 점수가 유의하게 더 높게 나타났으며( $p<.05)$, 과체중 여성들은 정상체중 여성들보다 LESS 총점도 유의하게 더 높게 나타났다( $p<.05)$. 그리고 드롭랜딩 후 수직점프 시 근육에 가해지는 부하를 측정하기 위하여 넙다리곧은근과 넙다리두갈래근의 근 활성 도를 측정한 결과, 과체중 여성들은 정상체중 여성들에 비하여 넙다 리곧은근에서 최대 근 활성도가 유의하게 더 높게 나타났다(p<.05).

착지 시 잘못된 자세는 부상과 밀접한 관련이 있으며, 무릎을 펴 서 착지하면 높은 충격력이 하지 관절에 부상을 유발시킨다(Hewett et al., 2006; Ford, Myer \& Hwett, 2003). 착지와 관련된 전방십자 인대 부상 메케니즘에서 무릎관절의 각도 변화는 중요한 요인이며 (Russell, Palmieri, Zinder \& Ingersoll, 2006), 착지 시 과도한 체중 은 근 골격계의 구조에 부하를 주어 부상을 유발시킨다(Goulding et al., 2000). 본 연구결과, 과체중 여성들은 정상체중 여성들에 비하여 무릎을 펴서 착지하여 무릎관절 각도가 더 작았으며, 이로 인하여 무 릎관절을 펴고 엉덩 관절을 굽히는 넙다리곧은근의 최대 근 활성도가 과체중 여성이 정상체중 여성에 비하여 더 높게 나타났다. 근 활성도 가 높게 나타났다는 것은 상대적으로 큰 부하가 근육에 전달되는 것 을 의미하며, 부상의 위험이 크다고 할 수 있다(Hewett et al., 2006; Ford et al., 2003).

Goulding et al.(2000)은 과도한 체중을 가진 사람들은 정상 체중 을 가진 사람들보다 하지 관절에 가해지는 큰 부하가 발생되어 하지 근 골격계에 많은 영향을 준다고 하였으며, Lee \& Jung(2018)은 체중 이 많이 나갈수록 무릎의 큰 부하로 인하여 근 피로도 증가할 수 있으 며 부상 유발의 위험 또한 증가될 수 있다고 하였다. 이와 같이 본 연 구에서 과체중 여성들은 정상체중 여성들에 비하여 무릎을 덜 굽혀서 착지하여 충격력을 충분히 흡수하지 못하여 정상체중 여성들에 비하 여 드롭랜딩 후 수직점프 시 전방십자인대 부상위험이 더 클 수 있을 것으로 사료된다.

착지 시 발생되는 충격력을 줄이기 위해서는 발뒤꿈치로 착지하는 방법보다 발의 앞쪽으로 착지를 해야 하며(Gross \& Nelson, 1988), 부상을 줄이기 위해서 가능한 몸통을 바로 세우고, 착지 후 빨리 안정 화하는 전략이 필요하다(Hewett et al., 2006; Ford et al., 2003). 본
연구의 LESS 영상 분석 결과, 대체적으로 과체중 여성들은 한 발씩 따 로 접촉하면서 착지하여 몸의 균형이 무너졌다. Smith et al.(2010)은 착지할 때 한 발씩 따로 떨어지면 신체의 균형 능력이 감소하게 되어 몸의 무게중심을 제어하지 못한다고 하면서 과체중이 균형을 유지하 는 능력을 저하시키는 한 가지 요인이라고 보고하였다.

본 연구에서 정상체중 여성과 과체중 여성들의 착지오류점수를 평 가하고 비교 분석한 결과, 과체중 여성들은 LESS 1 번 항목과 LESS 11 번 항목뿐만 아니라 각 항목을 더한 LESS 총점에서도 차이가 나타났 다. Padua et al.(2009)은 우수한 착지는 4점 이하, 좋은 착지는 4점 초과 5점 이하, 보통 착지는 5점 초과 6점 이하, 나쁜 착지는 6점 초과 로 정의하였으며, 본 연구에서 정상체중 여성들은 4.9점으로 좋은 착 지, 과체중 여성들은 7.4 점으로 나쁜 착지를 하고 있는 것을 알 수 있 었다. 즉, 과체중 여성들은 드롭수직점프 시 정상체중 여성들에 비해 과체중과 잘못된 자세로 착지하여 전방십자인대의 부상위험성이 더 높게 나타났다.

\section{최대무릎굴곡-최대무릎신전 구간(P2 phase)}

P2 구간은 수직점프하기 전의 무릎관절이 최대로 굴곡 되는 시점에서 무릎관절이 최대로 신전 되는 시점까지의 구간이다. $\mathrm{P} 2$ 구간은 몸통의 무게 중심을 중력의 반대반향으로 움직이면서 무릎관절 신전에 많은 힘을 요구한다(Ford et al., 2003).

본 연구의 LESS 분석과 근전도 분석 결과, 과체중 여성들은 정상체 중 여성들에 비하여 몸통이 앞으로 기울어져 있었다. 또한, 넙다리곧 은근에서 최대 근 활성도가 유의하게 더 높게 나타났다( $p<.05)$. 과체중 여성들은 무릎을 최대한 굽혔다가 무릎을 펼 때, 앞으로 기울어져있는 몸의 무게중심을 제어하지 못하여 넙다리곧은근의 최대 근활성도가 더 높게 나타났다.

넙다리곧은근의 최대 근 활성도가 높게 나타난 결과를 통하여 과체 중 여성들은 정상체중 여성들에 비하여 비대칭적인 근육 활성으로 인 하여 전방십자인대 부상의 위험에 더 노출되는 것을 알 수 있었다. 즉, 과체중 여성들은 정상체중 여성들에 비하여 더 많은 체중으로 무릎의 큰 부하를 줌으로써 근 피로도가 증가할 수 있고 부상위험 또한 증가될 수 있다(Lee \& Jung, 2018; Smith et al., 2010). 특히, 몸통의 무게가 증가함에 따라 드롭랜딩 후 수직점프를 하기 위해서 일어서려고 하는 동작 시 요추에 가해지는 부하도 증가하게 된다(Sibella, Galli, Romei, Montesano \& Crivellini, 2003). 따라서 과체중 여성들은 드롭랜딩 후 수직점프 시 정상체중 여성들에 비하여 부상 발생이 더 높을 수 있 다고 판단되며, 전방십자인대 부상을 방지하기 위하여 체중관리 외에 하지의 근력과 신체의 안정성도 증가시켜서 몸의 무게중심을 제어할 수 있도록 해야 한다.

Table 3. Muscle peak activities between normal and overweight females in $\mathrm{P} 1$ and $\mathrm{P} 2$ phase (unit: \%MVC, Mean \pm SD)

\begin{tabular}{clcccc}
\hline & & Normal & Overweight & $t$ & p \\
\hline \multirow{2}{*}{ P1 phase } & Rectus femoris & $110.63 \pm 44.40$ & $171.64 \pm 69.11$ & -2.228 & $.041^{*}$ \\
\hline \multirow{2}{*}{ P2 phase } & Biceps femoris & $68.69 \pm 54.01$ & $68.01 \pm 32.29$ & 0.32 & .975 \\
\hline
\end{tabular}

$* p<.05$ 


\section{결론 및 제언}

본 연구는 여성 집단 내에서 정상 체중과 과체중을 대상으로 드롭수직 점프 시 두 집단 간의 착지오류점수(LESS)와 하지의 근 활성도를 비교 분석하여 과체중 여성들의 전방십자인대 부상 위험요인을 규명하는 것이다. 과체중 여성들은 드롭수직점프 시 정상체중 여성들에 비하여 무릎을 덜 굽혀서 착지하여 무릎의 굴곡 각도가 더 작게 나타났으며, 두 발이 따로 착지하거나 발의 뒤쪽으로 착지하여 신체가 기울어지면 서 몸의 균형이 무너졌다. 또한, 과체중 여성들은 잘못된 자세로 착지 하여 정상체중 여성들에 비하여 LESS 총점이 더 높게 나타났다. 그리 고 넙다리곧은근의 근 활성도가 넙다리두갈래근 보다 높게 나타난 것 은 상대적으로 더 큰 부하가 근육에 전달된 것을 의미한다. 즉, 과체중 여성들은 정상체중 여성들에 비하여 더 많은 체중으로 의하여 무릎관 절에 가해지는 부하가 크고 충격력을 충분히 흡수하지 못하는 것을 의 미하며, 전방십자인대 부상 위험이 크다고 할 수 있다.

과체중 여성들은 드롭수직점프 시 전방십자인대 부상 방지를 위해서 는 무릎관절을 보다 굴곡 시키는 훈련과 착지 시 두 발이 앞쪽으로 동 시에 착지하도록 하는 훈련이 필요하다. 또한, 체중관리 외에도 자세교 정이나 하지의 근력을 강화하여 올바른 자세로 착지해야 할 것이다. 자 세와 근력 강화는 프로그램을 통하여 개선시킬 수 있기 때문에 추후 연 구에서는 정상체중 여성, 과체중 여성 그리고 비만인 여성들을 대상으 로 3차원 영상 분석과 근전도 분석, LESS 검사를 통한 연구가 이루어져 야 하며, 근력 및 신체 안정성 강화 훈련을 위한 구체적인 운동프로그 램 검증이 필요하다고 사료된다. 또한, 착지 패턴에 따라 방어기전 측 면에서 연구하고, 착지 거리에 따라 과체중 여성을 대상으로 한 LESS 를 검증하는 후속연구가 필요하다고 사료된다. 


\section{참고문헌}

Ahmad, C. S., Clark, A. M., Heilmann, N., Schoeb, J. S., Gardner, T. R., \& Levine, W. N. (2006). Effect of gender and maturity on quadriceps-to-hamstring strength ratio and anterior cruciate ligament laxity. American Journal of Sports Medicine, 34(3), 370-374.

Andersen, R. E., Crespo, C. J., Bartlett, S. J., Bathon, J. M., \& Fontaine, K. R. (2003). Relationship between body weight gain and significant knee, hip, and back pain in older American's. Obesity Research, 11(10), 1159-1162.

Cho, J. H., An, K. O., Cho, E. O., \& Lim, B. O. (2015). Analysis of Landing Error Scoring System during drop vertical jump on anterior cruciate ligament injury risk factors in female ballet dancers and female soccer players. Korean Journal of Sports Medicine, 33(2), 88-95.

Ford, K. R., Myer, G. D., \& Hwett, T. E. (2003). Valgus knee motion during landing in high school female and male basketball players. Medicine Science and Sports in Exercise, 35(10), 1745-1750.

Goulding, A., Taylor, R. W., Jones, I. E., McAuley, K. A., Manning, P. J., \& Williams, S. M. (2000). Overweight and obese children have low bone mass and area for their weight. International Journal of Obesity, 24, 627-632.

Gross, T. S., \& Nelson, R. C. (1988). The shock attenuation role of the ankle during landing from a vertical jump. Medicine and Science in Sports and Exercise, 20(5), 506-514.

Henlen, Daniels \& Worthingham. (2007). Muscle Testing. Saunders Company.

Hermens, H. J., Freriks, B., Merletti, R., Hagg, G., Stegeman D. F., Blok, J., Rau, G., \& Dissel-horst-Klug, C. (1999). Seniam 8: European Recommendations for Surface Electromyography, Roessingh Research and Development, ISBN 90-75452-15-2.

Hewett, T. E., Myer, G. D., \& Ford, K. R. (2006). Anterior cruciate ligament injuries in female athletes: Part 1, mechanisms and risk factors. American Journal of Sports Medicine, 34, 299-311.

Kim, K. W., \& Lim, B. O. (2011). Effects of female ages on the noncontact anterior cruciate ligament injury risk factors during the single legged drop landing. Korean Journal of Sport Science, 22(1), 1693-1700

Korean Society for the Study Obesity. (2018). Obesity medical guideline 2018, 5-6.

Lee, H. M., \& Jung, I. K. (2018). Relationship among obesity and metabolically health status, physical activities, and nutrient intakes in menopausal women. Journal of Korean Association Physical Education Sport Girls Women, 32(2), 131-152.

Lim, B. O. (2007). The effects of knee brace on the knee extensor and valgus moment during the rebound in female high school basketball player. Korean Journal of Physical Education, 46, 509-514.

Lim, B. O., \& Choi, I. A. (2009). Posterior cruciate ligament injury mechanism and biomechanics. Health \& Sports Medicine;
Official Journal of KACEP, 11(1), 75-83.

Moon, J. W., Cho, J. H., Lim, S. T., \& Lim, B. O. (2019). Analysis of landing error scoring system for evaluating the anterior cruciate ligament risk factors of muscle mass in female. Asian Journal of Kinesiology, 21(3), 15-22.

Padua, D. A., DiStefano, L. J., Beutler, A. I., Motte, S. J., DiStefano, M. J., \& Marshall, S. W. (2015). The Landing Error Scoring System as a screening tool for an anterior cruciate ligament injury-prevention program in elite-youth soccer athletes. Journal of athletic training, 50(6), 589-595.

Padua, D. A., Marshall, S. W., Boling, M. C., Thigpen, C. A., Garrett, W. E., \& Beutler, A. I. (2009). The Landing Error Scoring System (LESS) is a valid and reliable clinical assessment tool of jump-landing biomechanics: The JUMP-ACL study. American Journal of Sports Medicine, 37(10), 1996-2002.

Peng, H. T., Kernozek, T. W., \& Song, C. Y. (2010). Quadriceps and hamstring activation during drop jumps with changes in drop height. Physical Therapy in Sport, 12(3), 127-132.

Russell, K. A., Palmieri, R. M., Zinder, S. M., \& Ingersoll, C. D. (2006). Sex differences in valgus knee angle during a single-leg drop jump. Journal of Athletic Training, 41(2), 166-171.

Sibella, F., Galli, M., Romei, M., Montesano, A., \&Crivellini, M. (2003). Biomechanical analysis of sit-to-stand movement in normal and obese subjects. Clinical Biomechanics, 18(8), 745750 .

Smith, B., Roan, M., \& Lee, M. (2010). The effect of evenly distributed load carrying on lower body gait dynamics for normal weight and overweight subjects. Gait and Posture, 32(2), 176180. 


\title{
과체중 여성들의 드롭랜딩 후 수직점프 시 착지오류점수와 근 활성도를 통한 전방십자인대 부상 위험 요인 분석
}

\author{
황보민지 ${ }^{1}$, 임비오 ${ }^{2}$ \\ 1 중앙대학교 체육교육과 \\ 2 중앙대학교 체육교육과 교수
}

[목적] 본 연구는 여성 집단 내에서 정상 체중과 과체중을 대상으로 드롭수직점프 시 두 집단 간의 착지오류점수(LESS)와 하지의 근 활성도를 비교 분석하여 과체중 여성들의 전방십자인대 부상 위험요인을 규명하는 것이다.

[방법] 체질량지수 $18.5-22.9 \mathrm{~kg} / \mathrm{m}^{2}$ 내에 있는 10명, $23-24.9 \mathrm{~kg} / \mathrm{m}^{2}$ 내에 있는 10명을 대상으로 드롭랜딩 후 수직점프 과 제를 수행할 때, 정상 체중 여성과 과체중 여성의 집단 간 착지오류점수와 하지 근활성도 차이를 비교하기 위해서 독립표 본 t검정을 실시하였다.

[결과] 과체중 여성들은 드롭수직점프 시 정상체중 여성들에 비하여 무릎을 덜 굽혀서 착지하여 무릎의 굴곡 각도가 더 작게 나타났으며, 두 발이 따로 착지하거나 발의 뒤쪽으로 착지하여 신체가 기울어지면서 몸의 균형이 무너졌다. 또한, 과체중 여성들은 잘못된 자세로 착지하여 정상체중 여성들에 비하여 LESS 총점이 더 높게 나타났다. 그리고 넙다리곧은 근의 근 활성도가 넙다리두갈래근 보다 높게 나타났다.

[결론] 과체중 여성들은 정상체중 여성들에 비하여 더 많은 체중으로 의하여 무릎관절에 가해지는 부하가 크고 충격력을 충분히 흡수하지 못하여, 전방십자인대 부상 위험이 더 크다. 따라서 과체중 여성들은 드롭수직점프 시 전방십자인대 부 상 방지를 위해서는 무릎관절을 보다 굴곡 시키는 훈련과 착지 시 두 발이 앞쪽으로 동시에 착지하도록 하는 훈련이 필요 하다. 또한, 체중관리 외에도 자세교정이나 하지의 근력을 강화하여 올바른 자세로 착지해야 한다는 것을 시사한다.

주요어

과체중 여성, 전방십자인대, 착지오류점수시스템, 근 활성도 